\title{
Relationships of adolescents with suicidal behavior with social support networks
}

\author{
Relações de rede de apoio social do adolescente \\ com comportamento suicida \\ Relaciones de red de apoyo social del adolescente \\ con comportamiento suicida

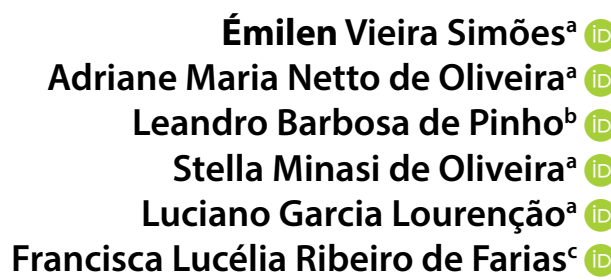

How to cite this article: Simões EV, Oliveira AMN, Pinho LB, Oliveira SM, Lourenção LG, Farias FLR. Relationships of adolescents with suicidal behavior with social support networks. Rev Gaúcha Enferm. 2022:43:e20210033. doi: https://doi.org/10.1590/19831447.2022.20210033 a Universidade Federal do Rio Grande (FURG), Escola de Enfermagem, Programa de Pós-Graduação em Enfermagem. Rio Grande, Rio Grande do Sul, Brasil. Universidade Federal do Rio Grande do Sul (UFRGS), Escola de Enfermagem, Programa de Pós-Graduação em Enfermagem. Porto Alegre, Rio Grande do Sul, Brasil.

Universidade de Fortaleza (UNIFOR). Centro de Ciências da Saúde. Departamento de Enfermagem. Fortaleza, Ceará, Brasil.

\section{ABSTRACT}

Objective: To identify the relationships of adolescents with suicidal behavior established with social support networks. Method: Qualitative study addressing ten adolescents with suicidal behavior cared for by a psychosocial care center attending children and adolescents located in southern Brazil. Semi-structured interviews were held in July 2020 via WhatsApp during the COVID-19 pandemic, and data were analyzed according to Minayo's thematic analysis.

Results: Two categories emerged: Dynamics of the relationships established in the family support network and Relationships established with the remaining social support network members, which revealed a weak social support network established with friends and at the school context.

Final considerations: This study enabled identifying how relationships are established in the social support networks and how these reflected on the adolescents' development.

Keywords: Suicide. Adolescent. Social support. Interpersonal relations. Mental health. Nursing.

\section{RESUMO}

Objetivo: Conhecer as relações de rede de apoio social do adolescente com comportamento suicida.

Método: Pesquisa qualitativa, realizada com dez adolescentes que apresentaram comportamento suicida, do Centro de Atenção Psicossocial Infanto Juvenil, em um município do sul do Brasil. As entrevistas semiestruturadas foram realizadas em julho de 2020 durante a pandemia da COVID-19, através do WhatsApp e os dados analisados conforme análise temática de conteúdo de Minayo.

Resultados: Foram divididos em duas categorias, dinâmica das relações na rede de apoio social intrafamiliar, na qual se conheceu fragilidades nas relações e um fortalecimento após intervenções dos profissionais de saúde e, relações com demais membros da rede de apoio social, evidenciou-se os adolescentes terem uma rede de apoio fragilizada com os amigos e no ambiente escolar.

Considerações finais: A pesquisa permitiu conhecer como são as relações de rede de apoio social e os reflexos dessa situação para o desenvolvimento do adolescente.

Palavras-chave: Suicídio. Adolescente. Apoio social. Relações interpessoais. Saúde mental. Enfermagem.

\section{RESUMEN}

Objetivo: Conocer las relaciones de la red de apoyo social del adolescente con comportamiento suicida.

Método: Investigación cualitativa, realizada en diez adolescentes, que presentaron comportamiento suicida, del Centro de Atención Psicosocial Infanto Juvenil, en un municipio en el sur de Brasil. Las entrevistas semiestructuradas fueron realizadas en julio de 2020, durante la pandemia del COVID-19, a través del WhatsApp; los datos fueron analizados de acuerdo con el análisis temático de contenido de Minayo.

Resultados: Los adolescentes fueron divididos en dos categorías a) dinámica de las relaciones en la red de apoyo social intrafamiliar, en la cual se conoció fragilidades en las relaciones y un fortalecimiento después de intervenciones de los profesionales de la salud y, b) relaciones con los demás miembros de la red de apoyo social. Se evidenció que los adolescentes tenían una red de apoyo fragilizada con los amigos y en el ambiente escolar.

Consideraciones finales: La investigación permitió conocer como son las relaciones de red de apoyo social y las repercusiones de esa situación para el desarrollo del adolescente.

Palabras clave: Suicidio. Adolescente. Apoyo social. Relaciones interpersonales. Salud mental. Enfermería. 


\section{INTRODUCTION}

A network concerns the relationships established between people, systems, and institutions playing different roles and are developed to facilitate the daily lives of people and communities. A network also serves to indicate which path(s) people can follow and which instruments (people and/or services) they can count on in a community context ${ }^{(1)}$. Social support networks are defined as a set of systems and people who make up existing relationship links perceived by an adolescent. Therefore, affections shown and felt by an adolescent constitute essential links for constructing and maintaining this support ${ }^{(2)}$.

Social and affective support available to adolescents is directly linked to living in their social environment, perceptions, and strategies used to establish bonds and relationships. The care and support provided by the family and community contribute to overcoming traumatic situations, which may occur throughout their development. Having these elements protects adolescents from diseases, psychopathological symptoms, and behavioral, cognitive, and affective changes manifested in the interaction with peers and family members, even when faced with vulnerable situations ${ }^{(2)}$.

However, frequent conflicts experienced in intra-family relationships and other social interactions make it difficult and may prevent adolescents from entering different contexts or strengthening affective bonds. However, early intervention on the part of health professionals and timely access to mental health treatment are considered protective factors in these $\operatorname{cases}^{(3)}$. The role of health institutions, schools, and the social support network is essential to develop interventions to prevent suicidal behavior and implement actions directed to adolescents and their families and the expanded support network ${ }^{(4)}$.

Suicidal behavior is a multifactorial phenomenon, including the characteristics of personality formation, self-esteem, relational and social factors, which include families' relationships, how families relate with friends, and others. Suicide may be attempted when communication and affections are predominantly negative, failing to strengthen individuals to face difficulties in daily life, leading to very low frustration tolerance and inability to overcome conflicts and losses ${ }^{(5)}$. Thus, to better understand the relationships established within the social support networks of adolescents with suicidal behavior from a town located in the extreme south of Brazil, the following research question was proposed in this study: How do the relationships within social support networks occur among adolescents with suicidal behavior? The objective is to identify the relationships established in the social support networks of adolescents with suicidal behavior.

This study was conducted in the context of the COVID-19 pandemic. Hence, data were collected online. The relevance of this study lies in the significant increase in suicide attempts and consummated suicides among young people in Brazil and worldwide ${ }^{(3)}$, a public health problem that is getting worse over time. Therefore, this study is expected to enable nurses to gain more profound knowledge about this subject, supporting the devise and implementation of suicide preventive actions and strategies intended to strengthen adolescents' relationships with support networks.

\section{METHOD}

This qualitative study derived from the master's thesis "Visibility of the attempt(s) of suicide from the discourses of teenagers", exploratory and descriptive in nature. The qualitative approach comprises the universe of meanings, reasons, aspirations, beliefs, values, and attitudes that are directly connected to interactions established among people ${ }^{(6)}$. This study's exploratory expectations concern the relationships established between adolescents and their social support networks. The COREQ script was used to collect data.

The study's setting was the Centro de Atenção Psicossocial Infanto-Juvenil (CAPSi) [Psychosocial Care Center for Children and Adolescents] located in Rio Grande, south of Brazil. CAP$S i$ is a psychosocial care service of universal access created to meet the needs of children and adolescents up to 17 years old presenting severe mental disorders, including their families in the treatment. Access to this facility occurs through practical training promoted by the Mental Health Nursing discipline, from the Undergraduate Nursing Program, or through a teaching internship within the graduate program. The first contact was established with the CAPSi psychologist, who provides care to adolescents who attempted suicide. She allowed access to the medical records and provided the telephone number of the adolescents' parents or legal guardians.

Seventeen adolescents who had attempted suicide were contacted via telephone. Because of the COVID-19 pandemic, they were receiving treatment online during the data collection period. Ten adolescents agreed to participate; three did not accept to participate in the study due to personal reasons; the parents of two adolescents did not authorize their participation for believing their children were not apt to talk about suicide; one adolescent had run away from home, and one adolescent was excluded because she was not able to answer for herself. 
Hence, the final sample was composed of ten adolescents who met the inclusion criteria: attending support groups and online sessions, having attempted suicide and being aged between 10 and 17 years, 11 months, and 29 days old (age limit for being cared for by CAPSi). In addition, exclusion criteria were: attending group sessions for less than three months because these individuals were still adapting to the treatment and, for this reason, were considered unable to talk about themselves.

Data were collected during the COVID-19 pandemic so that semi-structured interviews were held remotely in July 2020 through video or audio calls using WhatsApp. The semi-structured script contained open-ended questions that allowed participants to talk and express their feelings freely. The reports were recorded and transcribed verbatim to ensure the reliability of data. All the parents and legal guardians authorized the adolescents to participate in the study and audio recording via WhatsApp after reading free and informed consent forms. After their parents, all the adolescents consented to record the calls and agreed with the informed consent document.

The interviews were held from a room free of noise, displaying a calm environment, with an armchair, and a plant, so the place would feel cozy and safe. Confidentiality of information was also ensured. Note that formal training to collect data online was not provided to the Master student conducting the interviews. However, the researcher supervising the study is secretary of the city's Centro de Valorização da Vida e Prevenção do Suicídio [Life Valorization and Suicide Prevention Center] and received training to provide care via telephone and attended the Curso de Atualização em Saúde Mental e Atenção Psicossocial [Updating Course in Mental Health and Psychosocial Care] in 2020, which addressed online/remote assistance in crisis and disaster situations, promoted by FIOCRUZ. To preserve the participants' identities, they are identified by the letter " $\mathrm{A}$ " (which stands for adolescent) followed by the letter " $M$ " (male) or "F" (female) as self-reported, and by a number (1, 2, 3, etc.) that corresponds to the order of the interviews.

Data were analyzed according to Thematic Content Analysis from Minayo's perspective ${ }^{(6)}$. This method is defined as a set of techniques used to analyze communication, through which researchers construct knowledge based on discourses, aiming to identify not only the meaning of words but also implicit messages. This method comprises three stages, the first of which is the pre-analysis, in which the reports are read in detail, guided by the study's objective. The second stage refers to material exploration and categorization by grouping similar and different content identified in the adolescents' reports. Finally, the third stage refers to the interpretation of data. This stage enabled relating and interpreting data based on other authors addressing this research topic, revealing the meanings and results, also considering the participants' reports. As a result, two categories emerged from the analysis: Dynamics of the relationships established in the family support network and Relationships established with the remaining social support network members.

Regarding ethical principles, Resolution No. 466, from December 12 $2^{\text {th }}, 2012$, from the Conselho Nacional de Saúde (CNS) [National Council of Health] and Resolution No. 510, from April $7^{\text {th }}, 2016$, from the CNS/Ministry of Health, regulating research with human subjects were complied with. Additionally, the study was approved by the Institutional Review Board at the Universidade Federal do Rio Grande (CEP) FURG), and the Núcleo Municipal Educação em Saúde (NUMESC) at Rio Grande, opinion report No. 005/2020.

\section{RESULTS}

\section{Participants' Characteristics}

Nine out of the ten participants were female, and one reported being non-binary, i.e., a person who identifies her/ himself with the opposite sex and does not fit into the gender assigned to them. Binary individuals are neither exclusively and totally women or men; instead they may blend elements of one gender or another ${ }^{(7)}$. The adolescents' ages ranged from 12 to 17. Three lived with their mothers, four adolescents lived with both parents, and the stepfathers of three adolescents lived in the same household. All were students attending between the $6^{\text {th }}$ grade and $11^{\text {th }}$ grades and were receiving treatment from CAPSi between 5 and 24 months.

\section{Dynamics of the relationships established in the family support network}

The adolescents report that the relationships with the people living in the same household are harmonious and calm and they can mediate through dialogue and reach agreements harmoniously. In addition, some of the adolescents mentioned that, after receiving treatment and counseling from the CAPSi's professionals, the relationship with their families improved significantly, and parents and children started understanding each other better.

The relationship with my mom and my sister is good. We argue once in a while, but we always talk and respect each other. (AFO2) 
The relationship with my parents and my brothers and sisters was really awful before treatment at CAPSi started. It's better now, it's good. (AF04)

Our relationship is very calm, it's been much worse. At CAPSi, with the professionals' help, I could clarify a lot of things with my parents. (AF10)

Another participant considers she has a good relationship with her parents; however, she does not feel understood whenever she talks to her mother. This report shows some level of ambivalence, or perhaps, she does not have a clear definition or reference of a good relationship.

The relationship is good, though there were fights before! The relationship with my mother is good, but I can't talk to her because she doesn't understand anything I say. (AF08).

One adolescent mentioned she does not have anyone to talk to at home because everyone is busy, whether because they are at work or spend much time on their cell phones. Hence, the family members do not realize the adolescents need to talk and require attention. This family dynamics and culture seem to overlook conversations or unique opportunities and moments to express affection, pay attention to each other, simply talk, share positive affections, and understand how each other feels.

My sister and I barely talk. She has opinions different them mine; she spends a lot of time on her cell phone. My father is always on his phone, looking for something to do, or working, so we barely talk, and my mom is virtually always outside the home. So, as you can see, I don't have many people to talk to. (AFO6)

When asked about the people whom they liked the most and had the strongest emotional bond, the ten participants reported that it is with their mothers, but they also considered the bonds established with their siblings, grandmothers, grandfathers, and fathers to be significant. Even the participants who do not live with their fathers on a daily basis said they had positive feelings and affection toward them. The meaning of a positive affective bond and closeness to the people previously mentioned is manifested by relationships established over time, attention, affection, and availability to be with the adolescents in times of difficulty and vulnerability.

The persons I liked the most and have an affinity with are with those living with me, my family, my brothers, my grandpa, my grandma, my mother, and my father because they live with me for a long time. They're always with me. (AFO9)

Mystrongest bond is with my mom, my aunts, my father, my family; it's a bond established throughout life. I don't see my father much, but when I see him, there's always that father-daughter affection. (AF05)

I like my mom the most, and my cat, because they are the ones who understand me. (AF01).

When asked about the people they did not like and why they do not manifest affective bonds in these relationships, the adolescents mentioned close relatives such as a grandmother. Not having an affective bond occurs due to situations involving prejudice or homophobia. One of the participants reported psychological distress she experienced with her stepfather's mother.

\section{I don't like my grandmother. She's homophobic and didn't} accept me since I was a child. (AF03)

I don't like my stepfather's mother. [...] She used to say that I was fat and was always really rude to my mother and me. (AF07)

The adolescents'reports reveal fragile family relationships in terms of dialogue, attentive listening, understanding, and expressing feelings. This study shows that family dynamics do not allow new spaces to be constructed, opportunities for people to be taken into consideration and be respected, regardless of age. These reports encourage health workers, the academic community, and researchers to reflect on how they can promote greater flexibility among families with deeply rooted rigid relationships, so these families can support adolescents to form a healthier, safer, and independent personality toward adulthood.

\section{Relationships established with the remaining social support network members}

When the adolescents were asked about the relationships established with people from other contexts, most reported that they could count on other people besides their family support networks, such as the school support network and CAPSi, and one of the adolescents also mentioned her work environment. Five out of the ten adolescents considered they had a good relationship with people. The relevance of the interventions implemented by the CAPSi's health workers to improve these adolescents' wellbeing and the quality of their mental health is apparent. These improvements include establishing dialogues, being able 
to verbally and non-verbally express feelings, making new friends, and socializing with people at some level, considering that social relationships before the treatment were either very challenging or inexistent.

I get along with everyone. I have a good relationship with everybody at CAPSi. The psychologist there has already heard everything about me and has helped me a lot. (AFO2)

At the beginning is very difficult, I have difficulties socializing, I'm very quiet. I only get used with time, but CAPSi was a good thing and helped me make new friends. (AF05)

One adolescent believes she has difficulty socializing due to differing opinions regarding some subjects, which leads to arguments and conflicts. Another participant reports she does not like to talk to people with whom she has no relationship but considers herself extroverted and joyful with her friends.

I find it difficult to establish relationships with people. I'm a different person, and people don't like some things I say or do; we argue, and it's difficult. (AFO9)

I'm very quiet, mind my own business, don't like to talk much, but I'm extroverted with my friends and try to be fun with people. (AFO7)

Conflicting relationships in the workplace were considered relevant by one participant because she experienced prejudice toward her sexual orientation and her way of being, which negatively affected her mental health and triggered depressive symptoms.

I'd notice people judging and staring at me at work; my boss wouldn't allow me to dye my hair or paint my nails; she was prejudiced and affected me greatly. (ANB10)

Regarding social support networks, when the adolescents were asked about friendships, most reported having a small group of friends, while two participants reported no friends. Additionally, because of the COVID19 pandemic, which required people to comply with social distancing measures, those who reported friends kept contact with them only remotely, most through WhatsApp. The adolescents'reports revealed they had difficulties socially interacting with friends.

I have a friend, and we don't talk or see each other much, but whenever one of us needs the other, we are always there to help, and we keep a strong relationship. (AF01)
Those I consider to be my friends are those who were there with me in the most difficult times of my life. When I was depressive, this virtual friend, my ex-boyfriend, a guy I consider my brother, and friends who were by my side when I was giving up on life. (AFO3)

One adolescent reported she had no friends and mentioned loneliness because, at the time of the onset of depressive symptoms, she had no friends to give her emotional support and felt lonely. She considered her family members to be her friends.

I don't consider people my friends, because there was no one in the most difficult times of my life, there was nobody around when I tried to kill myself. (AFO6)

When asked to describe the relationships established with the social support network at school, with peers and teachers, eight out of the ten adolescents reported they had a good relationship with their teachers, emphasizing they had been welcomed when they needed support.

I have a good relationship at school, with the teachers. When I was feeling down and cried at school, they welcomed and talked to me. (AF02)

However, one participant reported that her school's principal bullied her, and another reported she felt unsafe at school, which triggered anxiety crises.

When I was little, I suffered a lot with bullying at school, including the principal, because I was fatter than the other girls. The principal didn't want me to wear shorts to school because the fat kept showing, while the other girls were allowed to wear shorts. (AF01)

I have problems only with this one teacher; I absorb everything bad about her. I used to have anxiety crises during classes and didn't want to go to classes. It's not anything specific I don't like about her; it's just that she gave bad vibes. (AF10)

In general, most adolescents considered it difficult to relate with peers within their social support network due to conflicts, difficulties in approaching people, bullying, changing schools, or because their classmates were not aware of the signs presented by adolescents with depression.

Three years had passed since I was bullied, but then, it happened again this year. One classmate started 
making fun of me because I'm tall and my hair is curly and voluminous. (AFO4)

I was unable to make new friends after/ changed schools and would stay by myself during breaks. And racism still happens nowadays... the way people look at me, treat me, I see it's different from the way they treat white people. (AF05)

The students in my previous school would make jokes I didn't like; they'd say I was fat, that I cut myself to make drama, that I was a drama queen. They'd make jokes about people with depression. (AF07)

The adolescents'reports revealed that most participants had difficulties changing environments due to their characteristics and personalities, which lead to shyness or a feeling that they were not accepted because of divergent opinions. On the one hand, these adolescents clearly distinguish between what is wrong and right in their lives. However, on the negative side, they are not very competent to relate to people who think differently, considering that differences are a good thing because, provided there is mutual respect, differences strengthen one's individuality and human relations.

\section{DISCUSSION}

The results show that the adolescents who attempted suicide strengthened their relationships with their family social support networks, especially with their mothers, after attending the Centro de Atenção Psicossocial Infanto-Juvenil (CAPSi), which enabled them to establish dialogues and acquire a better understanding between mother and child. The intervention of a qualified health professional takes into account many individual variables and the characteristics of the context to which adolescents belong. Proper guidance provided by health workers is associated with promoting well-being, preventing problem behaviors, decreasing stress, encouraging favorable outcomes, and promoting development toward adulthood ${ }^{(8)}$, as the adolescents'reports show.

This study shows that the health professionals' interventions helped the adolescents deal with their problems, and in some cases, their family members also changed their way of being and acting, which promoted changes in the family dynamics. Parents and children started dialoguing, anxiety and conflicts within the family context subsided, and understanding and mutual respect improved ${ }^{(8)}$. However, the family social support network still reveals many communication problems, sometimes with fathers and mothers. The mothers were considered the most significant persons. Perhaps, these difficulties remained because not all family members attend the treatment.
According to one study conducted in Malaysia, the role of the social support mediator is to enable adolescents to acquire a different perspective of the social support networks they can count on and encourage them to receive support from their families, friends, and other people that surround them ${ }^{(9)}$. The repercussions of interventions and decisions that concern the adolescents make them feel protected and safe in the family context. At this point, they feel understood by their family support network and understand and accept guidance for them to deal with their behaviors, ideas, feelings and are encouraged to make decisions to face life situations $s^{(8,10)}$.

Some adolescents mentioned that having a good relationship with their mothers and/or families was a supportive and protective factor against depression and suicide. One systematic review reports that a solid family relationship protects against risky behaviors such as suicide attempts. In addition, good parenting monitoring, and the support and involvement of parents in their children's daily routine, intending to meet the adolescents' needs, constructively support their decision-making, and promote emotional aspects that are vital for the healthy development of these individuals ${ }^{(4)}$.

One of the adolescents in this study reported she had a good relationship with her mother but did not feel understood, reporting that conversations always culminated in arguments. The international literature reports similar results regarding this aspect: parents who persistently maintain long conflicting relationships at home tend to assign more significant meanings to conflicts ${ }^{(10)}$. The author notes that when parents present such behavior, they cannot overcome conflicts as much as the adolescents, affecting their mental health and their relationships with the adolescents and other people within the family and social contexts. Hence, this situation reveals that parents need support as much as their children to modify behavior and qualify their interactions with others.

One study addressing 151 families of adolescents in Pennsylvania, United States, to identify their perceptions regarding family conflicts, reports that they believed that conflicts last long because they trigger other disorders within the family context, which leads to a continuous cycle of conflicting relations ${ }^{(10)}$. Thus, there is a need to implement interventions including all the family members linked to the adolescents, considering many weaknesses in the relationships and family social support network, which need to be strengthened to protect adolescents.

Another study conducted in the south of Sweden with more than 1,780 adolescents shows that parents who talk to their children and ask for information about them have fewer adolescents involved in vulnerable situations, such as 
robbery, intimidation, prejudice, bullying, and aggressive behavior ${ }^{(11)}$. Parents also provide social support, especially when adolescents experience personal problems or at school. The way parents monitor their children's lives may protect them from future risks. The more adolescents share and exchange information with their parents, the more family support is provided and the stronger the relationships ${ }^{(4)}$.

One of the participants reported that she does not have anyone to talk to at home because her family spends most of the time involved with social media. Thus, face-to-face interactions are replaced by virtual interactions in social media, revealing the chaotic context of current family and social relationships. In other words, families in the $21^{\text {st }}$ century lack close contact. This study was conducted during the COVID-19 pandemic, and the adolescents were complying with social distancing measures; thus, they were attending school and CAPSi only remotely, and at the same time, interaction difficulties remained at their homes. Similar findings are reported by a study conducted in Canada, which examined the association between computer-mediated communication and a feeling of loneliness experienced by Canadian youngsters. The Canadian study revealed that the daily use of social media might lead to estrangement among family members, considering there is a greater expectation of establishing virtual than face-to-face communication among those occupying the same physical space, which results in increasing difficulties to establish qualified communication within the family and in interpersonal relationships ${ }^{(12)}$.

Adolescents require the presence of their parents to meet their basic needs, among which emotional needs. One study investigating social support and protection against depression reports that support provided by mothers and fathers favors the adolescents' mental health and protects them against depression ${ }^{(13)}$. It shows the importance of both mother and father in the lives of adolescents. Accordingly, one of the participants reported and highlighted the affection existing between father and daughter, even though she does not see her father daily. The father's support is associated with decreased depressive symptoms and shows the importance of fathers to become involved with their children's healthy development ${ }^{(13)}$. One study conducted in Norway reports the importance of adolescents under joint parental custody to participate in support groups, as it helps them understand their thoughts and experiences, making them feel safe, promoting self-esteem, and helping them understand why their parents separated, establishing a space to promote health and strengthening their social support networks ${ }^{(14)}$.

As for the adolescents' friendships, the reports revealed social support networks with weak bonds, temporary relationships, ruptures, and few friends. In addition, some participants reported no friends or considered their family members to be their friends. Thus, adolescence is characterized by some level of instability in relationships, most of the time leading to multiple transformations in different contexts, among which, one's perception of friendships, when adolescents start demanding more from their relationships, asking for attention with a sense of $\mathrm{urgency}^{(8)}$. This instability probably occurs due to interpersonal challenges and difficulty understanding their mixed feelings that alternate due to psychopathological symptoms such as depression or anxiety ${ }^{(5)}$.

As reported by one of the participants, contact with friends was established remotely because of the pandemic; they were not allowed to meet people not living in the same household. One study addressing the association between mediated communication and loneliness reports that adolescents who spend time with social media daily more frequently experience emptiness, anxiety, and depression, as they allocate their time to activities other than face-to-face communication ${ }^{(12)}$.

One study addressing the quality of friendships and suicidal behavior among adolescents verified that children and adolescents who highly value companionship, recreation, care, and quality of friendship less frequently experienced interpersonal problems and were less likely to trigger depression symptoms ${ }^{(15)}$. Hence, we highlight the importance of strengthening support networks and having qualified professionals to recognize when adolescents feel lonely in times of instability in their lives, which may interfere with the quality of mental health and impose a need to reach for social support groups.

Poor social support, surrounded by conflicting and unstable relationships with friends, may influence adolescents' behaviors ${ }^{(15)}$. Friendships during adolescence, though, tend to be temporary and may be less reliable than support provided by parents and families. Additionally, adolescents with depressive symptoms may not be able to make friends during this phase of their life cycle due to characteristics such as excessive shyness, fear of peer rejection, low self-esteem, among other factors that negatively interfere in the construction of this social support network. Therefore, adults need to give examples and encourage adolescents to be brave and establish relationships with people of the same age ${ }^{(13)}$.

Data analysis revealed that the relationships established with the social support network in the school context, with teachers and classmates, differ from what is reported in the literature. The participants reported having a good relationship with teachers, especially when they experienced periods of fragility given their mental condition, and felt welcomed. This 
finding diverges from those reported in the literature. Even though teachers acknowledge that many suicide attempts occur among adolescents, in many schools, they often fail to recognize depressive symptoms in their workplaces, and for this reason, ignore the students'behaviors ${ }^{(14)}$. Social support provided by those in the school context is vital to prevent suicidal thoughts and behaviors, as the environment may cause psychological distress, considering excessive demands from school or families for adolescents to attain excellence in school performance ${ }^{(16)}$.

Evidence presented by the State University of California regarding the role of social support among adolescents practicing self-injuries and attempting suicide shows that greater support provided by good relationships established with teachers and classmates is directly linked to significantly lower suicidal behaviors, making adolescents realize consistent protective factors within the school context ${ }^{(17)}$. In addition, the teachers' motivational influence becomes a protective factor even among adolescents at a high risk of attempting suicide. For this reason, the involvement of teachers with students, encouraging them to seek success at school and in life, is highly relevant and helps adolescents overcome problems internalized in other contexts, promoting their self-esteem and potentialities.

In this study, the relationship established with classmates was not a protective factor for the adolescents; instead, these relationships caused them intense suffering caused by racism, social isolation, and bullying on the part of one school's principal. In addition, studies show that children and adolescents who are humiliated and experience physical or psychological violence from their families perform poorly at school, which is a significant risk for involvement with aggressive behavior, compared to individuals who do not experience such events ${ }^{(18)}$.

Bullying is a problem arising from the first experiences established by human beings. In the family context, it is generally characterized by repeated actions and behaviors such as not experiencing much affection, authoritarian practices, physical punishment, parental rejection, and a perception, during childhood, of a weak social support network that persists into adolescence and adulthood. Individuals who live in a family that express negative affections such as hostility, anger or sorrow, are more likely to experience relationship problems with peers and a deficit in their ability to interpret events in life and process information, which interfere with their social and emotional skills, especially at schoo( ${ }^{(19)}$.

Hence, a school support network surrounded by positive relationships between students and teachers decreases bullying and, consequently, suicidal behavior. As adolescents establish a protective relationship with teachers, they are more likely to feel cared for and less likely to become involved with risky behavior. In addition, this relationship makes them realize that it is possible to establish safe bonds and positive relationships with other people(20).

\section{FINAL CONSIDERATIONS}

The objective set in this study to identify the relationships established within social support networks of adolescents with suicidal behavior was achieved. Adolescents and family support networks need to be strengthened by health professionals so that adolescents learn about themselves better and understand how interactions with others affect them. Otherwise, they may become vulnerable to the conflicts existing in different contexts, which may intensify suicidal behaviors.

Interventions implemented by health professionals are intended to strengthen these social support networks, seeking to improve these individuals' self-esteem and encouraging them to establish healthy interactions in the most diverse environments. Hence, nursing workers must identify these relationships to welcome adolescents in the most diverse contexts, such as primary health care provided at schools, home visits, and the most different healthcare settings, including CAPSi. The objective is to implement care strategies such as attentive listening and promote opportunities to meet and talk with this population and reflect upon the role of nurses in developing actions to prevent suicide behaviors by mapping families in vulnerable situations in the territory.

This study's limitations include the impossibility of conducting the interviews face-to-face given the protocols in force at the time due to the COVID-19 pandemic, which may have hindered rapport established between the researcher and adolescents, possibly preventing them from sharing details regarding their relationships that they would report otherwise.

\section{REFERENCES}

1. Dias CN, Guzzo RSL. Escola e demais redes de proteção: aproximações e atuações (im)possíveis? Pesqui Prát Psicossociais. 2018 [cited 2020 0ct 21];13(3):e1848. Available from: http://www.seer.ufsj.edu.br/index.php/revista_ppp/article/ view/3061/1964.

2. Silva ACS, Alberto MFP. Fios soltos da rede de proteção dos direitos das crianças e adolescentes. Psicol Cienc Prof. 2019;39:e185358. doi: http://doi. org/10.1590/1982-3703003185358.

3. Ministério da Saúde (BR). Fundação Oswaldo Cruz. Saúde mental e atenção psicossocial na pandemia COVID-19: suicídio na pandemia COVID-19 [Internet]. Rio de Janeiro: Fiocruz, 2020 [cited 2020 0ct 21]. Available from: https://www. arca.fiocruz.br/bitstream/icict/41420/2/Cartilha_PrevencaoSuicidioPandemia. pdf. 
4. Zappe JG, Dapper F. Drogadição na adolescência: família como fator de risco ou proteção. Rev Psicol IMED. 2017;9(1):140-58.doi: https://doi.org/10.18256/21755027.2017.v9i1.1616.

5. Oliveira DCD. 0 impacto do suporte social, depressão, ansiedade e impulsividade na adolescência: relação com os comportamentos autolesivos e a ideação suicida. [Dissertação]. Lisboa: Instituto Universitário Ciências Psicológicas, Sociais e da Vida; 2019 [cited 2020 Aug 8]. Available from: https://core.ac.uk/ reader/288868463.

6. Minayo MCS. 0 desafio do conhecimento: pesquisa qualitativa em saúde. 14. ed. São Paulo: Hucitec, 2014.

7. Reis N, Pinho R. Gêneros não-binários: identidades, expressões e educação. Reflex Ação. 2016;24(1):7-25. doi: http://doi.org/10.17058/rea.v24i1.7045.

8. Tessaro D, Schmidt B. Escolha profissional: teoria e intervenções sistêmicas voltadas ao adolescente e à família. Pensando Fam. 2017 [cited 2020 Sep 7];21(1):92-104. Available from: http://pepsic.bvsalud.org/pdf/penf/v21n1/ v21n1a08.pdf.

9. Tan CS, Low SK, Viapude GN. Extraversion and happiness: the mediating role of social support and hope. Psych J. 2018;7(3):133-43. doi: https://doi.org/10.1002/ pchj.220.

10. LoBraico EJ, Brinberg M, Ram N, Fosco GM. Exploring processes in day-to-day parent-adolescent conflict and angry mood: evidence for circular causality. Fam Process. 2020;59(4):1706-21. doi: https://doi.org/10.1111/famp. 12506.

11. Kapetanovic S, Boele S, Skoog T. Parent-adolescent communication and adolescent delinquency: unraveling within-family processes from between-family differences. J Youth Adolesc. 2019;48(9):1707-23. doi: https://doi.org/10.1007/ s10964-019-01043-W.

12. Favotto L, Michaelson V, PickettW, Davison C. The role of family and computermediated communication in adolescent loneliness. PLoSOne. 2019;14(6):e0214617. doi: https://doi.org/10.1371/journal.pone.0214617.
13. Gariépy G, Honkaniemi H, Quesnel-Vallée A. Social support and protection from depression: systematic review of current findings in Western countries. $\mathrm{Br} J$ Psychiatry. 2016;209(4):284-93. doi: https://doi.org/10.1192/bjp.bp.115.169094.

14. Johnsen I0, Litland AS, Hallström IK. Living in two worlds - children's experiences after their parents'divorce - a qualitative study. J Pediatr Nurs. 2018;43:e44-e51. doi: https://doi.org/10.1016/j.pedn.2018.09.003.

15. Evans R, Hurrell C. The role of schools in children and young people's self-harm and suicide: systematic review and meta-ethnography of qualitative research. BMC Public Health. 2016;16:401. doi: https://doi.org/10.1186/s12889-016-3065-2.

16. Wan Y, Chen R, Ma S, McFeeters D, Sun Y, Hao J, Tao F. Associations of adverse childhood experiences and social support with self-injurious behaviour and suicidality in adolescents. Br J Psychiatry. 2019;214(3):146-52. doi: https://doi. org/10.1192/bjp.2018.263.

17. Forster M, Grigsby TJ, Gower AL, Mehus CJ, McMorris BJ. The role of social support in the association between childhood adversity and adolescent self-injury and suicide: findings from a statewide sample of high school students. J Youth Adolesc. 2020;49:1195-208. doi: https://doi.org/10.1007/s10964-020-01235-9.

18. Oliveira WA, Silva JL, Sampaio JMC, Silva MAl. Students' health: an integrative review on family and bullying. Ciênc Saúde Colet. 2017;22(5):1553-64. doi: https://doi.org/10.1590/1413-81232017225.09802015.

19. Fora CAMP. A influência da expressividade familiar, percecionada por adolescentes, no desenvolvimento de sintomas emocionais e de problemas de relacionamento com os colegas. [Dissertação]. Coimbra: Faculdades de Psicologia e Ciências da Educação da Universidade de Coimbra; 2017 [cited 2020 Aug 12]. Available from: https://estudogeral.sib.uc.pt/bitstream/10316/84078/1/Tese\%20Psicologia\%20 do\%20desenvolvimento\%20final2017.pdf

20. Han Z, Fu M, Liu C, Guo J. Bullying and suicidality in urban chinese youth: the role of teacher-student relationships. Cyberpsychol Behav Soc Netw. 2018;21(5):28793. doi: https://doi.org/10.1089/cyber.2017.0484. 


\section{- Acknowledgments:}

To the Master's Program in Nursing at the Universidade Federal do Rio Grande - FURG. To the Núcleo Municipal de Educação em Saúde Coletiva (NUMESC) and Centro de Atenção Psicossocial Infanto Juvenil in Rio Grande.

\section{- Authorship contribution:}

Conceptualization - Émilen Vieira Simões, Adriane Maria Netto de Oliveira.

Data curation - Émilen Vieira Simões, Adriane Maria Netto de Oliveira.

Formal analysis - Émilen Vieira Simões, Adriane Maria Netto de Oliveira.

Investigation - Émilen Vieira Simões, Adriane Maria Netto de Oliveira. Methodology - Émilen Vieira Simões, Adriane Maria Netto de Oliveira.

Project administration - Émilen Vieira Simões, Adriane Maria Netto de Oliveira.

Resources - Émilen Vieira Simões.

Supervision - Émilen Vieira Simões, Adriane Maria

Netto de Oliveira.

Validation - Émilen Vieira Simões, Adriane Maria Netto de Oliveira, Leandro Barbosa de Pinho, Stella Minasi de Oliveira, Luciano Garcia Lourenção and Francisca Lucélia Ribeiro de Farias.

Visualization - Émilen Vieira Simões, Adriane Maria Netto de Oliveira.

Redaction - Émilen Vieira Simões, Adriane Maria Netto de Oliveira, Leandro Barbosa de Pinho, Stella Minasi de Oliveira, Luciano Garcia Lourenção, and Francisca Lucélia Ribeiro de Farias.

The authors declare no conflicts of interest.

\section{- Corresponding author:}

Émilen Vieira Simões

Email:emi-dp@hotmail.com

\section{Associate editor:}

Dagmar Elaine Kaiser

\section{Editor-in-chief:}

Approved: 07.09.2021
Maria da Graça Oliveira Crossetti 